\title{
TINGKAT MOTIVASI PETANI DALAM BETERNAK SAPI DI KECAMATAN SAMBAS KABUPATEN SAMBAS
}

\author{
Harmoko ${ }^{1}$ \\ ${ }^{1}$ Mahasiswa Program Studi Agrobisnis Jurusan Agribisnis \\ Politeknik Negeri Sambas \\ email:harmoko.ok@gmail.com
}

\begin{abstract}
Farmers as cattle ranchers, the impetus for raising cows can provide benefits. In addition to the results from farming, cattle results can be used as a "treasure savings". The presumption treasure savings in rural communities in the form of livestock that can provide benefits when needed at the times when it was needed the money. The purpose of this study to determine the level of motivation of farmers to raise cattle and determine the factors that influence it. The research uses descriptive analytical method that aims to describe the motivation of farmers to raise cattle. Samples taken at random from a group of farmers in the villages in the subdistrict of Sambas. Analysis of data using multiple regression. The results showed that the level of motivation of farmers to raise cattle is very high. Factors that affect the motivation of farmers to raise cattle is attitude. In order for farmers positive attitude, do increase the capacity of farmers through workshops, seminar and workshops themed livestock.
\end{abstract}

Keywords: farmer, raising cattle, motivation

\section{PENDAHULUAN}

Kondisi geografis dan ekologis khususnya Kecamatan Sambas memiliki potensi untuk usaha ternak sapi. Potensi itu berupa dataran rendah dengan beragam jenis rerumputan yang dapat dimanfaatkan sebagai makanan ternak sapi. Usaha ternak tersebut banyak dimiliki masyarakat yang tinggal di wilayah pedesaan.

Usaha ternak sapi bukan usaha baru bagi masyarakat pedesaan khususnya petani di Kecamatan Sambas. Jumlah Usaha ternak sapi cukup dominan dibanding usaha ternak lain, hal ini disebabkan karena sapi memiliki harga jual yang tinggi. Permintaan akan daging sapi selalu tinggi ketika hari besar seperti Idul Fitri dan Idul Adha. Momen atau "event" hari-hari besar tersebut menjadi waktu utama masyarakat melepas atau menjual ternak sapi.

Melihat usaha ternak sapi dengan permintaan pasar yang relatif stabil dengan harga yang tinggi ketika hari besar tentunya memiliki dampak positif pada masyarakat khususnya peternak. Dampak tersebut berupa peningkatan usaha di wilayah pedesaan dengan terciptanya lapangan kerja baru. Beberapa lapangan usaha baru tercipta berupa jasa penyediaan pakan, pengolahan limbah ternak dan jasa pemasaran ternak.

Bagi petani selaku peternak sapi, doron- gan untuk beternak sapi dapat memberikan manfaat. Manfaat tersebut dapat berupa peningkatan pendapatan keluarga. Selain hasil dari usahatani, hasil ternak sapi dapat digunakan sebagai "harta tabungan". Anggapan harta tabungan dalam masyarakat pedesaan berupa hewan ternak yang dapat memberikan manfaat ketika diperlukan pada waktu-waktu ketika sedang memerlukan uang.

Dalam memilih sampai menjalankan aktifitas usaha ternak sapi sedikit banyaknya dipengaruhi oleh beberapa faktor. Faktor tersebut salah satunya adalah motivasi. Motivasi merupakan latar belakang individu untuk melakukan tindakan atau berperilaku. Jika beternak sapi memiliki dampak atau hasil yang baik, maka petani berusaha lebih baik agar usaha yang dijalankan dapat memperoleh hasil. Hal ini seperti pendapat Asnawi (2007) yang menyatakan, seseorang menginginkan hal-hal yang baik sehingga daya penggerak yang memotivasi semangat seseorang terkandung dari harapan yang akan diperoleh di masa depan.

Dorongan untuk berusaha ternak sapi memiliki konsekuensi pada curahan waktu petani. Aktifitas harian yang dikerjakan oleh petani akan lebih banyak. Selain merawat usahatani yang diusahakan sebagai usaha pokok, 
pekerjaan tambahan untuk ternak sapi juga memerlukan aktifitas yang tidak sedikit. Aktifitas yang dikerjakan oleh petani seperti mencari rumput, membersihkan kandang dan kegiatan perawatan lainnya. Aktifitas yang tersebut merupakan gambaran motivasi seseorang dalam berperilaku.

Aktifitas petani dengan beternak sapi tentunya menambah aktifitas yang lebih banyak. Dengan jumlah yang tidak sedikit tersebut tentunya ada faktor yang mempengaruhi. Faktor-faktor yang mempengaruhi dapat bersumber dari dalam (internal) individu petani maupun dari luar (eksternal) individu. Faktor-faktor tersebut merupakan faktor pendorong motivasi individu. Asnawi (2007) menjelaskan bahwa selain motivasi, perlu adanya dorongan dari faktor internal dan faktor eksternal untuk membuat seseorang memutuskan sesuatu.

Dorongan untuk beternak sapi sebagai usaha sampingan petani tentunya berlaku pada komunitas petani di desa. Namun dorongan dari masing-masing individu petani dapat berbeda-beda. Hal tersebut disebabkan oleh latar belakang individu petani. Latar belakang individu dari masing-masing petani tentunya memberikan perilaku berbeda yang dapat dilihat dari hasil usahanya

Berpijak dari kerangka pikir seperti itu maka studi tentang motivasi petani dalam beternak sapi penting dilakukan. Untuk itu kajian mengenai dorongan yang melatar belakangi motivasi petani utuk beternak sapi serta faktor-faktor yang mempengaruhinya diidentifikasi lebih lanjut. Hasil studi diharapkan bermanfaat sebagai informasi dasar dalam peningkatan kapasitas hasil pembangunan sumberdaya manusia pertanian.

Motivasi petani beternak sapi dapat dipengaruhi dari beberapa faktor. Faktor tersebut dapat berasal dari individu petani seperti sikap, umur, dan pendidikan. Sedangkan faktor yang berasal dari luar individu berupa jumlah tanggungan keluarga, penyuluhan dan jumlah ternak sapi. Sikap merupakan unsur pembentuk perilaku manusia yang terdiri dari kognitif, afektif dan psikomotorik (Azwar, 1995).

Sikap manusia dapat dipengaruhi oleh lingkungan sekitar. Hasil penelitian Mulyadi (2011) menjelaskan bahwa perilaku petani dalam pengelolaan pertanian berwawasan lingkungan dipengaruhi oleh kearifan lokal yang berlaku di wilayah penelitian. Semakin besar determinan kearifan lokal terhadap perilaku manusia di suatu wilayah, maka individu yang ada di dalamnya akan mengikutinya. Sehingga semakin besar pengaruh kearifan lokal maka motivasi petani untuk berperilaku berwawasan lingkungan semakin tinggi.

Luanmase, dkk (2011) dalam laporan penelitiannya menjelaskan bahwa karakteristik peternak lokal dan transmigrasi berupa umur, tingkat pendidikan, dan jumlah tanggungan keluarga berpengaruh terhadap motivasi peternak. Semakin bertambah umur peternak maka motivasi semakin tinggi. Dengan bertambahnya umur, ilmu dan pengalaman beternak sapi akan semakin baik. Hal ini berkorelasi positif terhadap motivasi peternak.

Sedangkan tingkat pendidikan juga berpengaruh terhadap tingkat motivasi peternak. Semakin bertambah tingkat pendidikan maka motivasi peternak untuk beternak sapi semakin tinggi. Tingkat pendidikan merupakan proses individu dalam menjalani pendidikan formal. Semakin bertambah waktu untuk menghabiskan tingkat pendidikan akan berpengaruh secara positif terhadap meningkatnya motivasi.

Begitu juga dengan jumlah tanggungan keluarga, semakin sedikit jumlah anggota keluarga maka akan meningkatkan motivasi. Artinya jika jumlah anggota keluarga kecil, maka hasil pendapatan dari beternak dapat ditabung. Petani dengan jumlah anggota kelurga yang kecil cenderung memiliki motivasi yang besar untuk beternak sapi.

Luanmase, dkk (2011) hasil penelitiannya menjelaskan bahwa motivasi peternak dipengaruhi oleh dorongan ekonomi. Beberapa hal yang menjadi dorongan ekonomi diantaranya : penggunaan input sarana produksi yang kecil, hanya menggunakan tenaga kerja keluarga, cepat mengembalikan modal dan pendapatan keluarga meningkat. Sedangkan faktor-faktor yang mepengaruhi motivasi diantaranya pengalaman beternak, jumlah tanggungan keluarga dan luas lahan. Hasil penelitian tersebut menyimpulkan bahwa ada perbedaan antara motivasi peternak lokal dan peternak transmigrasi.

Berdasarkan variabel motivasi oleh Hendarto, dkk (2012) menjelaskan hasil penelitiannya bahwa luas lahan yang dimiliki petani tidak berpengaruh terhadap motivasi. Hal ini disebabkan luas lahan yang dimiliki petani dengan kategori luas maupun sempit dapat memberikan hasil produki yang sama. Hasil produksi 
tersebut dapat untuk membayar pinjaman setiap bulannya. Namun Luanmase, dkk (2011) hasil penelitiannya menjelaskan luas lahan yang dimiliki petani berpengaruh nyata terhadap motivasi. Hasil penelitian tersebut melaporkan bahwa luas lahan pertanian yang dimiliki petani banyak terdapat hijau makanan ternak (HMT). Faktor makanan ternak ini yang diduga mempengaruhi motivasi. Artinya semakin luas lahan dengan hijauan makanan ternak, maka semakin tinggi motivasi petani untuk beternak sapi.

Sedangkan variabel jumlah ternak sapi merupakan kuantitas ternak yang dimiliki atau dipelihara oleh petani. Jumlah ternak sapi berhubungan dengan tujuan beternak. Petani dengan jumlah sapi yang sedikit umumnya hanya sebagai usaha sampingan dari usahatani. Seperti hasil penelitian Rahmat (2008) menjelaskan bahwa ternak domba dengan tujuan untuk sampingan dan usaha utama berpengaruh terhadap motivasi peternak. Peternak domba dengan tujuan usaha sampingan memiliki jumlah ternak domba yang relatif sedikit dibanding peternak dengan tujuan usaha utama. Peternak domba dengan tujuan komersil akan meningkatkan jumlah dan kualitas dombanya, terutama jenis tangkas. Semakin banyak dan baik kualitas domba, maka semakin tinggi pula harga jualnya. Faktor harga ini yang diduga sebagai faktor pendorong motivasi peternak.

Peran penyuluh pertanian dalam mendorong motivasi petani dapat dilakukan saat melakukan kegiatan penyuluhan. Sehingga secara tidak langsung kegiatan penyuluhan yang diselenggarakan oleh penyuluh lapangan dapat merubah pengetahuan petani. Dari perubahan pengetahuan dalam hal penambahan informasi diharapkan mampu menambah motivasi petani. Seperti penelitian Risna, dkk (2012), peran penyuluh pertanian berupa edukasi dan fasilitasi mampu meningkatkan peran petani dalam pengendalian hama terpadu pada tanaman padi. Peran edukasi dan fasilitasi merupakan pendampingan penyuluh pertanian dalam memberikan pelayanan kepada petani. Peran edukasi berupa pendidikan dan pengajaran, dalam hal ini pendidikan non formal kepada petani. Sedangkan peran fasilitasi berupa menjembatani dan mengakses kebutuhan petani.

Dari uraian variabel hasil dari beberapa penelitian, maka dapat ditarik kesimpulan bahwa motivasi merupakan faktor pendorong individu untuk bertindak atau melakukan sesuatu. Moti- vasi sendiri dapat dipengaruhi oleh faktor-faktor yang berasal dari dalam dan lingkungan sekitar individu. Kebutuhan yang ingin dicapai setiap individu tentunya berbeda-beda. Begitu juga dengan petani yang memiliki motivasi berbeda antara individu satu dengan individu lainnya. Meskipun profesi, tempat tinggal, dan status sosial lainnya hampir sama tentunya motivasi yang dimiliki belum tentu serupa.

Gambaran pemenuhan kebutuhan individu tersebut dapat dijelaskan dengan teori motivasi Alderfer. Teori motivasi Aldefer mendasarkan pendekatan atas faktor-faktor kebutuhan dan kepuasan individu, yang menyebabkan berperilaku dengan cara tertentu, (Gitosudarmo dan Nyoman, 1997). Teori ini memusatkan pada faktor-faktor dalam diri individu yang menguatkan, mengarahkan, mendukung dan memperhatikan perilakunya. Teori ini mencoba menjawab kebutuhan apa yang memuaskan dan mendorong semangat kerja seseorang adalah untuk memenuhi kebutuhan dan kepuasan materil yang diperoleh dari hasil kerjanya. Dengan landasan teori tersebut, penelitian ini bertujuan untuk mengetahui tingkat motivasi petani dalam beternak sapi dan mengetahui faktor-faktor yang mempengaruhi motivasi petani.

\section{METODE PENELITIAN}

Sesuai dengan tujuan yang ingin dicapai, penelitian ini menggunakan metode deskriptif analitis. Metode deskriptif analitis ini bertujuan untuk melukiskan tentang motivasi petani beternak sapi. Metode ini menggambarkan konteks lokal dan apa yang terjadi di dalamnya serta memperlihatkan aturan dan alasan yang menentukan mengapa hal-hal tersebut terjadi pada sekelompok manusia, suatu objek, suatu sistem ataupun suatu peristiwa pada masa sekarang (Nasir, 1998).

Penelitian dilaksanakan pada bulan Desember Tahun 2013 sampai Februari Tahun 2014. Lokasi penelitian dilakukan di Kecamatan Sambas, Kabupaten sambas. Penentuan lokasi penelitian dipilih secara purposive dengan pertimbangan desa yang memiliki kelompok tani yang aktif. Desa tersebut adalah Desa Sei Rambah, Saing Rambi dan Kartiasa. Kelompok tani dipilih secara purposive dengan pertimbangan memiliki anggota yang beternak sapi. Kelompok tani yang dipilih dari empat desa tersebut berjumlah empat kelompok. Dari kelompok tani kemudian dipilih petani secara random sebagai 
sampel. Jumlah sampel yang diperoleh 50 petani. Teknik pengumpuan data menggunakan wawancara dengan panduan kuisioner. Teknik penentuan skor dalam penelitian ini menggunakan skala likert. Pemilihan likert didasarkan pada pendapat Azwar (1995), yang menyebutkan skala dapat digunakan dalam pernyataan sikap individu. Skala likert ditetapkan melalui pendekatan deviasi normal $(Z)$ dengan tujuan untuk memberi skor dari masing-masing jawaban. Untuk tiap-tiap item diperoleh skor antara 1,2,3,4 dan 5. Sangat Setuju (5), Setuju (4), Ragu-ragu (3), Tidak Setuju (2), dan Sangat Tidak Setuju (1).

Tujuan pertama, untuk mengetahui tingkat motivasi petani. Untuk mengetahui tingkat motivasi digunakan analisis statistik deskriptif. Untuk menguji tujuan kedua digunakan analisis regresi berganda. Dalam uji regresi berganda, analisis ditujukan untuk mengetahui variabel independen yang berpengaruh terhadap variabel dependen. Variabel independen dalam penelitian ini adalah sikap, umur, pendidikan, jumlah tanggungan keluarga, penyuluhan dan jumlah ternak sapi. Sedang variabel dependen adalah motivasi. Persamaan regresi yang digunakan sebagai berikut :

$\mathrm{Y}=\mathrm{a}+\mathrm{b}_{1} \mathrm{X}_{1}+\mathrm{b}_{2} \mathrm{X}_{2}+\mathrm{b}_{3} \mathrm{X}_{3}+\mathrm{b}_{4} \mathrm{X}_{4}+\mathrm{b}_{5} \mathrm{X}_{5}+\mathrm{b}_{5} \mathrm{X}_{5}+$ $\mathrm{b}_{6}+\mathrm{X}_{6}+\mathrm{e}$

Keterangan :

$\mathrm{Y}=$ motivasi petani dalam beternak sapi

a $\quad=$ Nilai konstanta

$\mathrm{b}_{1}-\mathrm{b}_{4} \quad=$ koefisien regresi

$\mathrm{X}_{1}=$ sikap

$\mathrm{X}_{2} \quad=$ pendidikan

$\mathrm{X}_{3}=$ umur

$\mathrm{X}_{4} \quad=$ jumlah tanggungan keluarga

$\mathrm{X}_{5} \quad=$ penyuluhan

$\mathrm{X}_{6} \quad=$ jumlah ternak sapi

$\mathrm{e} \quad=$ error

\section{HASIL DAN PEMBAHASAN}

Kecamatan Sambas mempunyai luas wilayah 246,66 km². Letak Kecamatan Sambas terletak antara $1^{\circ} 11^{\prime} 20^{\prime \prime}$ - $1^{\circ} 24^{\prime} 48^{\prime \prime} \mathrm{LU}$ dan $109^{\circ} 09^{\prime} 16^{\prime \prime}$ - 109 26'23" BT. Secara geografis Kecamatan Sambas terletak $265 \mathrm{Km}$ arah utara Kota Pontianak Ibukota Kalimantan Barat. Jenis ternak (ruminansia) yang menjadi usaha oleh peternak di Kecamatan Sambas yang memiliki populasi terbesar adalah kambing 922 ekor, sapi 838 ekor dan babi 443 ekor, Anonim (2011).

Karakteristik adalah sifat-sifat individu yang melekat atau menjadi ciri khas dalam kehidu- pan. Karakteristik individu dalam penelitian ini berupa faktor internal dan eksternal yang dimiliki responden (petani), yaitu : umur, tingkat pendidikan, pekerjaan pokok, jumlah tanggungan keluarga, dan jumlah ternak. Gambaran karakteristik responden disajikan pada Tabel 1 .

Umur merupakan lamanya usia hidup yang telah dijalani petani. Dalam penelitian ini terdapat umur petani dibagi menjadi dari umur produktif dan umur tidak produktif (tua). Berdasarkan UU Tenaga Kerja No. 14 Tahun 1969, kurang dari atau sama dengan 14 tahun kurang produktif, 15 sampai 54 tahun produktif dan lebih dari 55 tahun tidak produktif. Kategori umur produktif yaitu 17 - 55 tahun, dan kategori umur tua $56-$ 67 tahun. Berdasarkan Tabel 1, distribusi petani menurut umur diketahui umur kategori produktif lebih dominan dibanding tidak produktif.

Pendidikan merupakan jenjang formal yang pernah ditempuh oleh petani dengan satuan tahun. Sekolah dasar lamanya pendidikan 6 tahun, sekolah menengah pertama 9 tahun dan sekolah menengah atas 12 tahun. Dalam penelitian ini, tingkat pendidikan petani disesuaikan dengan tingkat pendidikan yang ada yaitu SD, SMP, SMA dan perguruan tinggi. Berdasarkan Tabel 1, tingkat pendidikan petani sebagian besar umumnya adalah SD dan SMP. Persentase tersebut ditunjukkan 38\% SD dan 34\% SMP. Hal ini mengindikasikan bahwa tingkat pendidikan petani masih rendah. Dinamika yang dapat dicermati adalah, petani belum memiliki inisiatif, kreatifitas dan belum mendukung kelompok tani sebagai unit usaha. Sedangkan $28 \%$ petani dengan pendidikan SMA. Pekerjaan pokok yang dominan adalah petani, dengan persentase $64 \%$. Sedangkan sisanya $36 \%$ sebagai pekerja swasta, wiraswasta dan PNS.

Jumlah tanggungan keluarga merupakan jumlah anggota keluarga yang masih menjadi tanggungan kepala keluarga. Berdasarkan Tabel 1, jumlah tanggungan keluarga yang paling banyak adalah kategori sedang yaitu jumlah 3 -5 orang tanggungan. Kondisi ini sangat dominan, karena umumnya petani memiliki anak 2-3 orang. Jumlah tersebut belum termasuk saudara dari isteri atau suami. Jumlah keluarga dapat menjadi tenaga kerja dalam skala usahatani rumah tangga 
Tabel 1. Karakteristik Responden

\begin{tabular}{|c|c|c|c|c|}
\hline No & Karakteristik & Kategori & Jumlah (org) & Persentase (\%) \\
\hline \multirow[t]{2}{*}{1} & Umur & $17-55$ (produktif) & 40 & 80 \\
\hline & & $56-67$ (tidak produktif) & 10 & 20 \\
\hline \multirow[t]{4}{*}{2} & Pendidikan & $\mathrm{SD}$ & 19 & 38 \\
\hline & & SMP & 17 & 34 \\
\hline & & SMA & 14 & 28 \\
\hline & & Perguruan Tinggi & 0 & 0 \\
\hline \multirow[t]{2}{*}{3} & Pekerjaan & Petani & 32 & 64 \\
\hline & & Lainnya & 8 & 36 \\
\hline \multirow[t]{3}{*}{4} & Tanggungan & $0-2$ (sedikit) & 12 & 24 \\
\hline & Koluros & $3-5$ (sedang) & 32 & 64 \\
\hline & Neruarga & $6-8$ (banyak) & 6 & 12 \\
\hline \multirow[t]{3}{*}{5} & Jumlah Ternak & $1-3$ (sedikit) & 34 & 68 \\
\hline & & $4-6$ (sedang) & 13 & 26 \\
\hline & & $7-9$ (banyak) & 3 & 6 \\
\hline
\end{tabular}

Sumber : Analisis Data Primer, 2014

Penyuluhan dalam hal ini dilihat dari frekuensi petani mengikuti kegiatan. Kegiatan penyuluhan dapat diselenggarakan melalui kelompok maupun kehadiran penyuluh. Sebagian besar petani $68 \%$ mengikuti kegiatan penyuluhan 3 sampai 4 kali dalam kurun waktu satu bulan terakhir. Jumlah ternak merupakan banyaknya ternak sapi yang dipelihara oleh petani. Jumlah ternak dikategorikan menjadi sedikit, sedang dan banyak. Berdasarkan Tabel 5.5, banyaknya ternak yang menjadi peliharaan petani adalah kategori sedikit, yaitu 1-3 ekor. Jumlah tersebut 34 orang dengan presentasi $68 \%$. Jumlah ternak tersebut umumnya berasal dari induk betina yang secara biologis berkembang biak beranak dalam setiap tahunnya.

\section{Motivasi Petani Dalam Beternak Sapi}

Motivasi merupakan dorongan dari dalam individu untuk melakukan sesuatu perbuatan. Begitu juga halnya dalam beternak sapi, petani memilih beternak dengan dasar atau dorongan dari dalam individu masing-masing. Hal yang mendorong petani untuk memelihara sapi sebagai usaha sampingan bertani dapat didasari dari indikator motivasi ERG. Tabel 2 menjelaskan item pertanyaan motivasi mulai dari indikator existence berupa dorongan untuk memperoleh kebutuhan pokok. Kebutuhan pokok berupa pangan sandang, papan dan kebutuhan pelengkap dalam rumah tangga. Pada kebutuhan existence ini, petani sebagian besar dengan rata-rata

$50 \%$ sangat ingin agar kebutuhannya dapat dipenuhi melalui beternak sapi.

Selanjutnya pada motivasi petani, dorongan akan relatednes yaitu ingin selalu berinteraksi dengan orang di lingkungannya. Berdasarkan tabel 2, sebagian besar petani atau dengan rata-rata $52,8 \%$ ingin selalu berinteraksi dengan petani, PPL, dan orang-orang lain yang berhubungan dengan peternakan sapi.

Motivasi berikutnya pada tabel 2 adalah growth yaitu dorongan ingin tumbuh dan berkembang. Dorongan ini selalu ingin mendapatkan hal yang mampu menjadikan seseorang lebih berprestasi sehingga diakui oleh orang disekitarnya. Diantara dorongan tersebut berupa ingin mendapatkan pengetahuan, informasi dan teknologi serta jaringan dalam memasarkan ternak. Petani yang memiliki dorongan ini memiliki rata-rata $40 \%$, sisanya pada range ragu dan tidak ingin.

Untuk mengetahui tingkat motivasi ditentukan melaui penghitungan skor. Skor tertinggi diperoleh dengan perkalian antara skor tinggi (5) dengan jumlah item pertanyaan dari masing-masing indikator motivasi. Skor minimum diperoleh dari perkalian antara skor terendah (1) dengan jumlah item pertanyaan. Tabel 3 berikut merupakan hasil perhitungan skor dari masing-masing item pertanyaan, selanjutnya dibuat kategori dengan menghitung rerata. Sehingga tingkat motivasi digunakan dua kategori yaitu tertinggi dan terendah dengan menghitung frekuensi hasil skor jawaban responden. 
Tabel 2. Sebaran Indikator Motivasi

\begin{tabular}{|c|c|c|c|c|c|c|c|c|c|}
\hline \multirow[t]{3}{*}{ No } & \multirow[t]{3}{*}{ Item yang ditanyakan } & \multicolumn{8}{|c|}{ Jawaban } \\
\hline & & \multicolumn{2}{|c|}{ SI } & \multicolumn{2}{|c|}{ I } & \multicolumn{2}{|c|}{$\mathrm{R}$} & \multicolumn{2}{|c|}{ TI } \\
\hline & & $\mathrm{n}$ & $\%$ & $\mathrm{n}$ & $\%$ & $\mathrm{n}$ & $\%$ & $\mathrm{n}$ & $\%$ \\
\hline 1. & Kebutuhan dapat terpenuhi & 27 & 54 & 14 & 28 & 9 & 18 & & \\
\hline 2. & Dapat memenuhi kebutuhan sandang & 19 & 38 & 18 & 36 & 13 & 26 & & \\
\hline 3. & $\begin{array}{l}\text { Dapat membeli kebutuhan-kebutuhan pe- } \\
\text { lengkap }\end{array}$ & 20 & 40 & 16 & 32 & 12 & 24 & 2 & 4 \\
\hline 4. & Dapat memberikan pendapatan keluarga & 25 & 50 & 14 & 28 & 11 & 22 & & \\
\hline 5. & Dapat memiliki tabungan & 27 & 54 & 18 & 36 & 4 & 8 & 1 & 2 \\
\hline 6. & $\begin{array}{l}\text { Ingin memiliki teman yang beternak dalam } \\
\text { kelompok }\end{array}$ & 24 & 48 & 18 & 36 & 8 & 16 & & \\
\hline 7. & $\begin{array}{l}\text { Ingin mengenal petani sukses dalam beter- } \\
\text { nak sapi }\end{array}$ & 25 & 50 & 18 & 36 & 7 & 14 & & \\
\hline 8. & $\begin{array}{l}\text { Akrab dengan petani, PPL dan orang yang } \\
\text { beternak sapi }\end{array}$ & 25 & 50 & 14 & 28 & 11 & 22 & & \\
\hline 9. & $\begin{array}{l}\text { Dekat dengan jaringan peternak dalam dan } \\
\text { luar desa }\end{array}$ & 24 & 48 & 21 & 42 & 5 & 10 & & \\
\hline 10. & $\begin{array}{l}\text { Dapat berbagi pengalaman dengan petani } \\
\text { lain }\end{array}$ & 34 & 68 & 11 & 22 & 5 & 10 & & \\
\hline 11. & 11. Menambah pengetahuan dalam beternak & 25 & 50 & 13 & 26 & 12 & 24 & & \\
\hline 12. & $\begin{array}{l}\text { Menambah keterampilan dalam memelihara } \\
\text { sapi }\end{array}$ & 24 & 48 & 12 & 24 & 10 & 20 & 4 & 8 \\
\hline 13. & $\begin{array}{l}\text { Memperluas jaringan pasar dan kebutuhan } \\
\text { ternak sapi }\end{array}$ & 13 & 26 & 24 & 48 & 8 & 16 & 5 & 10 \\
\hline 14. & $\begin{array}{l}\text { Mendapatkan informasi dan teknologi dalam } \\
\text { beternak }\end{array}$ & 20 & 40 & 16 & 32 & 14 & 24 & & \\
\hline 15. & $\begin{array}{l}\text { Menambah informasi dalam saluran } \\
\text { pemasaran ternak }\end{array}$ & 27 & 54 & 13 & 26 & 10 & 20 & & \\
\hline
\end{tabular}

Berdasarkan tabel 3, sebagian petani memiliki tingkat motivasi yang tinggi. Dari jumlah responden 50 orang $94 \%$ atau 47 orang berkategori tinggi. Sedangkan sisanya $6 \%$ atau hanya 3 orang memiliki kategori rendah. Hal tersebut sesuai dengan tabel 2 dari indikator motivasi, sebagian besar responden memiliki dorongan untuk memenuhi kebutuhannya melalui beternak sapi. Berdasarkan indikator motivasi berupa dorongan untuk memperoleh kebutuhan utama, kebutuhan akan berinteraksi dan kebutuhan akan berprestasi memiliki kecenderungan yang tinggi. Kecenderungan ini sesuai dengan jawaban yang diberikan responden.

Indikasi dari tingkat motivasi yang tinggi tersebut, petani akan selalu berupaya menjaga dan mempertahankan ternak sapi sebagai usaha sampingan utama. Setelah menggarap lahan pertanian sebagai usaha pokok, usaha ternak sapi menjadi pilihan utama kedua. Hampir setiap tahun peternak menjual ternak sapi ketika hari besar seperti Idul Fitri dan Idul Adha. Selanjutnya hasil penjualan tersebut diinvestasikan kembali dengan membeli bakalan ternak sapi kembali.

Aktivitas tersebut terlihat dari peremajaan ternak sapi dengan kehadiran bakalan baru setiap tahun pada masing-masing kandang yang dimiliki petani. Selain itu aktivitas pedagang daging sapi atau orang-orang yang mencari ternak sapi untuk dijual menjadi ramai. Intensitasnya akan tinggi ketika menjelang hari besar seperti Idul Fitri dan Idul Adha.

Kecenderungan motivasi yang tergambar tersebut merupakan dorongan untuk memperoleh mencukupi kebutuhan dalam hal ini motif ekonomi. Hal ini sesuai dengan hasil penelitian dari dari Luanmase, dkk (2011), Hendarto, dkk (2012) dan Rahmat (2008) yang menyimpulkan 
Tabel 3. Distribusi Petani Menurut Indikator Relatednes (Berhubungan) dalam Beternak Sapi

\begin{tabular}{clcc}
\hline No & \multicolumn{1}{c}{ Relatedness } & Jumlah (orang) & Persentase (\%) \\
\hline 1 & Tinggi $(19-25)$ & 46 & 92 \\
2 & Sedang $(11,6-18)$ & 4 & 8 \\
3 & Rendah $(5-11,5)$ & 0 & 0 \\
\hline & Jumlah & $\mathbf{5 0}$ & $\mathbf{1 0 0}$
\end{tabular}

bahwa dorongan motivasi untuk melaksanakan sesuatu kegiatan adalah motif ekonomi. Motif ekonomi merupakan salah satu pemenuhan kebutuhan dasar manusia yang digunakan untuk memenuhi makan, minum, sandang dan papan. Kebutuhan tersebut yang menjadi dorongan petani beternak

\section{Faktor-faktor Yang Mempengaruhi Motivasi Petani dalam Beternak Sapi}

Faktor-faktor yang berpengaruh terhadap tingkat motivasi petani adalah faktor internal. Faktor internal yang dimiliki petani diantaranya sikap, pendidikan, umur tanggungan keluarga dan jumlah ternak. Sedangkan faktor eksternal adalah faktor yang datang dari luar individu petani yaitu penyuluhan. Untuk menjawab tujuan kedua yaitu faktor-faktor yang mempengaruhi motivasi digunakan uji regresi berganda. Hasil uji regresi berganda disajikan pada tabel 4 . Hasil analisis regresi menunjukkan uji variabel dengan motivasi. Variabel yang berpengaruh terhadap motivasi adalah sikap. Variabel sikap memiliki thitung 2,340 dengan taraf signifikansi 0,001 . Nilai koefisien regresi yang dihasilkan bernilai positif. Artinya nilai positif menunjukkan bahwa semakin positif nilai sikap maka motivasi petani dalam beternak sapi semakin tinggi. Motivasi petani dalam beternak sapi akan tinggi jika sikap petani terhadap ternak sapi juga mendukung. Berikut hasil pengukuran sikap disajikan pada tabel 5 .

Pada pengukuran sikap, item pertanyaan terdiri dari komponen kognitif, afeksi dan konasi. Indikator tersebut merupakan standar dalam pengukuran sikap. Sehingga akan diperoleh konsistensi dari jawaban responden. Skor jawaban mengikuti skala likert. Sangat setuju (SS) skor 5, Setuju (S) skor 4, Ragu-ragu (R) skor 3, Tidak setuju (TS) skor 2 dan Sangat tidak setuju (STS) skor 1.

Pada indikator kognitif pada pertanyaan 1 sampai 6 rata-rata $46 \%$ responden menjawab sangat setuju dan setuju. Hal tersebut mengindikasikan ranah pengetahuan responden dalam beternak sapi sangat baik. Pada indikator afektif yang tertulis pada pertanyaan 7 sampai 12 rata-rata 46,67 responden menjawab setuju dengan konsisten pertanyaan unfavorable nomor 11 dan 12. Sedangkan pada indikator konasi yaitu kecenderungan bertindak pada pertanyaan 13 sampai 18 rata-rata $44 \%$ responden menjawab setuju yang artinya antara sikap dan perbuatan memiliki konsistensi dengan kategori kuat. Sikap petani terhadap ternak sapi artinya positif. Semakin positif sikap maka kecenderungan untuk mendukung dan bertindak akan semakin tinggi.

Tabel 4. Hasil Analisis Regresi, Faktor-faktor yang Mempengaruhi Motivasi Petani dalam Beternak Sapi

\begin{tabular}{|c|c|c|c|c|}
\hline No & Variabel & Koefisien Regresi & t-hitung & Signifikansi \\
\hline 1 & Sikap & 0,577 & 2,340 & 0,023 \\
\hline 2 & Pendidikan & 0,033 & 0,074 & 0,941 \\
\hline 3 & Umur & $-0,009$ & $-0,076$ & 0,939 \\
\hline 4 & Tanggungan Keluarga & 0,594 & 0,767 & 0,447 \\
\hline 5 & Penyuluhan & $-0,343$ & $-2,560$ & 0,014 \\
\hline 6 & Jumlah Ternak & $-0,770$ & $-1,218$ & 0,229 \\
\hline & $\begin{array}{ll}\text { Konstanta } & =44,375 \\
\mathrm{R}^{2} & =0,202 \\
\mathrm{~F}_{\text {hitung }} & =1,811 \\
\mathrm{Sig} & =0,001 \\
\alpha & =0,05\end{array}$ & & & \\
\hline
\end{tabular}


Tabel 5. Pengukuran Sikap Petani

\begin{tabular}{|c|c|c|c|c|c|c|c|c|c|c|c|}
\hline \multirow{3}{*}{ No. } & \multirow{3}{*}{ Item Pertanyaan } & \multicolumn{10}{|c|}{ Jawaban } \\
\hline & & \multicolumn{2}{|c|}{ SS } & \multicolumn{2}{|c|}{$\mathbf{S}$} & \multicolumn{2}{|c|}{$\mathbf{R}$} & \multicolumn{2}{|c|}{ TS } & \multicolumn{2}{|c|}{ STS } \\
\hline & & $\mathrm{n}$ & $\%$ & $\mathrm{n}$ & $\%$ & $\mathrm{n}$ & $\%$ & $\mathrm{n}$ & $\%$ & $\mathrm{n}$ & $\%$ \\
\hline 1. & $\begin{array}{l}\text { Sapi sebagai penghasil sumber pan- } \\
\text { gan hewani }\end{array}$ & 35 & 70 & 13 & 26 & 2 & 4 & & & & \\
\hline 2. & $\begin{array}{l}\text { Sumber pakan dapat berupa konsen- } \\
\text { trat }\end{array}$ & 30 & 60 & 18 & 36 & 2 & 4 & & & & \\
\hline 3. & $\begin{array}{l}\text { Sapi merupakan salah satu ternak } \\
\text { ruminansia }\end{array}$ & 16 & 32 & 34 & 68 & & & & & & \\
\hline 4. & $\begin{array}{l}\text { Limbah dapat dimanfaatkan sebagai } \\
\text { bahan organik }\end{array}$ & 17 & 34 & 28 & 56 & 5 & 10 & & & & \\
\hline 5. & Bobot sapi dapat mencapai 1 ton & 26 & 52 & 22 & 44 & 2 & 4 & & & & \\
\hline 6. & $\begin{array}{l}\text { Ternak sapi merupakan salah satu } \\
\text { bentuk investasi }\end{array}$ & 14 & 28 & 23 & 46 & 3 & 6 & 10 & 20 & & \\
\hline 7. & Beternak sapi sangat mudah & 11 & 22 & 35 & 70 & 4 & 8 & & & & \\
\hline 8. & Senang dalam merawat sapi & 16 & 32 & 34 & 68 & & & & & & \\
\hline 9. & $\begin{array}{l}\text { Senang dengan memanfaatkan lim- } \\
\text { bah sapi }\end{array}$ & 19 & 38 & 30 & 60 & 1 & 2 & & & & \\
\hline 10. & $\begin{array}{l}\text { Menyediakan dan mencari pakan } \\
\text { sapi sangat mudah }\end{array}$ & 8 & 16 & 38 & 76 & 4 & 8 & & & & \\
\hline 11. & $\begin{array}{l}\text { Tidak suka dengan sistem pemeliha- } \\
\text { raan bersama kelompok }\end{array}$ & 10 & 20 & 3 & 6 & & 34 & 20 & 40 & & \\
\hline 12. & $\begin{array}{l}\text { Sedih jika setiap petani memiliki } \\
\text { ternak sapi }\end{array}$ & 2 & 4 & 3 & 6 & 3 & 6 & 20 & 40 & 22 & 44 \\
\hline 13. & $\begin{array}{l}\text { Menjaga dan merawat agar ternak } \\
\text { sehat }\end{array}$ & 36 & 72 & 13 & 26 & 1 & 2 & & & & \\
\hline 14. & $\begin{array}{l}\text { Memanfaatkan konsentrat sebagai } \\
\text { makanan tambahan }\end{array}$ & 8 & 16 & 34 & 68 & 4 & 8 & 2 & 4 & 2 & 4 \\
\hline 15. & $\begin{array}{l}\text { Mengikuti anjuran cara beternak } \\
\text { dari PPL }\end{array}$ & 11 & 22 & 33 & 66 & 6 & 12 & & & & \\
\hline 16. & $\begin{array}{l}\text { Memanfaatkan dan menggunakan } \\
\text { limbah }\end{array}$ & 12 & 24 & 35 & 70 & 2 & 4 & 1 & 2 & & \\
\hline 17. & $\begin{array}{l}\text { Tidak akan berbagi pengalaman } \\
\text { kepada orang lain }\end{array}$ & 1 & 2 & 2 & 4 & 7 & 14 & 17 & 34 & 23 & 46 \\
\hline 18. & $\begin{array}{l}\text { Mengikuti inovasi terbaru dalam } \\
\text { beternak }\end{array}$ & 26 & 52 & 20 & 40 & 2 & 4 & 1 & 2 & 1 & 2 \\
\hline
\end{tabular}

Untuk mengetahui kategori sikap responden, maka dihitung dengan perkalian antara skor tinggi (5) dengan jumlah item pertanyaan dari masing-masing indikator motivasi. Skor minimum diperoleh dari perkalian antara skor terendah (1) dengan jumlah item pertanyaan. Hasil perhitungan skor dari masing-masing item pertanyaan, selanjutnya dibuat kategori dengan menghitung rerata. Sehingga sikap digunakan dua kategori yaitu tertinggi dan terendah dengan menghitung frekuensi hasil skor jawaban responden.
Berdasarkan tabel 6, dari skor yang diperoleh dari item pertanyaan rerata 70,76 , nilai terendah 18 dan tertinggi 83, maka interval nilai kategori dibuat menjadi dua yaitu positi dan negatif. Distribusi responden dengan kategori positif sebesar $100 \%$ artinya responden memiliki kategori sikap mendukung dalam beternak sapi.

Sikap petani terhadap ternak sapi sangat positif, karena ternak sebagai hewan piaraan memiliki dimensi ekonomi yang tinggi. Sikap 
Tabel 6. Kategori Sikap

\begin{tabular}{llrr}
\hline No & Sikap & \multicolumn{2}{c}{ Jumlah } \\
\cline { 3 - 4 } & & Orang & Persentase (\%) \\
\hline 1 & Positif $(50,6-83)$ & 50 & 100 \\
2 & Negatif $(18-50,5)$ & 0 & 0 \\
\hline \multicolumn{2}{l}{ Jumlah } & 50 & 100 \\
\hline
\end{tabular}

merupakan bagian dari perilaku yang masih dalam ranah afektif. Afektif merupakan kecenderungan bertindak yang didasari dari pengetahuan (kognitif). Jika pengetahuan petani dalam beternak baik, maka kecenderungan sikap akan positif. Hal ini dapat dilihat dari indikator motivasi yang memiliki sebaran jumlah responden yang dominan tinggi.

Berdasarkan hasil tersebut, sikap petani terhadap ternak sapi memiliki pengaruh yang nyata terhadap motivasi. Sikap petani cenderung mendukung dalam hal ini setuju bahwa dengan beternak sapi akan meningkatkan pendapatan dalam keluarga. Oleh karena itu, sebagian besar petani yang beternak sapi memiliki pandangan bahwa dengan beternak sapi akan memiliki pendapatan yang lebih dari hasil menjual hasil ternaknya nanti. Fakta ini sesuai pendapat Hariadi (2011) bahwa, sikap seseorang akan memberikan warna dan corak pada perilaku atau perbuatan orang yang bersangkutan. Apabila mengetahui sikap seseorang, maka akan dapat menduga bagaimana respons atau perilaku yang akan diambil oleh orang tersebut.

Variabel pendidikan, umur, jumlah tanggungan keluarga, penyuluhan dan jumlah ternak tidak berpengaruh terhadap motivasi petani. Pendidikan tidak berpengaruh terhadap motivasi karena tingkat pendidikan tidak memberikan pengaruh langsung terhadap teknis beternak sapi. Artinya petani dengan tingkat pendidikan tinggi dan rendah memiliki motivasi yang sama dalam beternak sapi.

Petani dengan umur produktif dan tidak produktif memiliki motivasi yang sama dalam beternak sapi. Umur produktif tergolong umur muda sedangkan umur tidak produktif golongan umur tua. Antara petani dengan umur muda dan tua hampir tidak ada kesulitan dalam beternak sapi. Sapi yang dipelihara umumnya dikandangkan dengan pemberian pakan berupa rumput segar. Aktifitas berupa mencari rumput untuk pakan sapi dapat dikerjakan oleh petani dengan umur produktif dan umur yang tidak produktif Jumlah tanggungan keluarga dalam peneli- tian ini dikategorikan menjadi sedikit, sedang dan banyak. Jumlah tanggungan keluarga tidak berpengaruh terhadap motivasi karena petani tanggungan keluarga berupa isteri dan anak umumnya bukan menjadi tenaga kerja dalam usaha ternak sapi. Fakta tersebut dipertegas dengan aktifitas petani yang terlibat secara individu dalam memelihara ternak sapi. Mulai membersihkan kandang, mencari pakan rumput, merawat ternak dan perawatan kelengkapan lainnya seperti perawatan kandang sapi.

Variabel penyuluhan tidak berpengaruh terhadap motivasi karena kegiatan penyuluhan yang umumnya diikuti oleh petani jarang memberikan materi tentang ternak sapi. Namun kegiatan penyuluhan yang diselenggarakan selalu diikuti oleh petani. Sehingga frekuensi kehadiran dalam kegiatan penyuluhanpun tidak berpengaruh terhadap motivasi petani. Sebagian besar petani memperoleh informasi tentang ternak dari masyarakat sekitar yang sama-sama beternak sapi. Informasi yang diperoleh tersebut lebih lengkap dan sesuai dengan kebutuhan jika dibandingkan dengan kegiatan penyuluhan yang diselenggarakan oleh tenaga penyuluh lapangan. Jumlah ternak yang dimiliki petani tidak berpengaruh terhadap motivasi. Jumlah ternak yang dimiliki petani dibagi dalam kategori sedikit, sedang dan banyak. Jumlah ternak yang dimiliki petani cenderung sedikit yaitu 1 sampai 3 ekor. Jumlah tersebut mendominasi kepemilikan ternak oleh petani karena sebagian besar petani baru memulai usaha ternak. Selain itu, petani memelihara ternak dengan cara penggemukkan sapi bakalan yang dibeli pada usia 6-8 bulan. Setelah ternak memiliki bobot yang cukup dan layak untuk dijual petani melepasnyal pada momen Idul Fitri, Idul Adha atau dijual kepada pedagang pada hari biasa.

\section{KESIMPULAN DAN SARAN}

Tingkat motivasi petani dalam beternak sapi di Kecamatan Sambas dalam kategori tinggi, motivasi tersebut ditandai melalui indikator motivasi yang menunjukkan seluruh petani san- 
gat ingin memenuhi kebutuhan melalui salah satunya dengan beternak sapi dan faktor-faktor yang mempengaruhi motivasi petani dalam beternak sapi adalah faktor internal yaitu sikap.

Untuk menjaga motivasi petani dalam menjalankan usaha ternak sapi, dapat dilakukan melalui bimbingan penyuluhan, pertemuan rutin berupa diskusi, latihan, magang dan kunjungan ke kelompok ternak lain yang lebih maju. Agar sikap petani positif, dapat dilakukan peningkatan kapasitas petani melalui ceramah workshop, seminar dan sarasehan yang bertemakan peternakan.

\section{DAFTAR PUSTAKA}

Asnawi, S. 2007. Teori Motivasi : Dalam Pendekatan Psikologi Industri dan Organisasi. Cetakan ke-3. Studi Press. Jakarta

Azwar, S. 1995. Sikap Manusia, Teori dan Pengukurannya. Pustaka Pelajar. Yogyakarta

Hariadi, Sunarru SH. 2011. Dinamika Kelompok, Teori dan Aplikasinya untuk Analisis Keberhasilan Kelompok Tani sebagai Unit Belajar, Kerjasama, Produksi dan Bisnis Sekolah Pasca Sarjana. UGM Press. Yogyakarta

Hendarto, Badrudin, Redy, dan Yuliarso, M. Zulkarnaen. 2012. Faktor-faktor Yang Berhubungan Dengan Tingkat Motivasi Petani Sawit Dalam Pengembalian Kredit di Koperasi Baitul Maal Wataunwil Desa Srikaton Kecamatan Pondok Kelapa Kabupaten Bengkulu Tengah. Jurnal Agrisep Volume 11, No. 1 2012. Prodi Agribisnis Jurusan Sosial Ekonomi Pertanian, Fakultas Pertanian Univesitas Bengkulu www. portalgaruda.org.: diakses tanggal 14 April 2014.

Luanmase, Christian Manase, Nurtini, Sudi dan Haryadi, F. Trisakti. Analisis Motivasi Bernak Sapi Potong Bagi Peternak Lokal dan Transmigran Serta Pengaruhnya Terhadap Pendapatan di Kecamatan Kairatu, Kabupaten Seram Barat. Buletin Peternakan Volume 35, No. 2. 2011. Fakultas Peternakan UGM. www.portalgaruda.org : diakses tanggal 14 April 2014.
Mulyadi. 2011. Pengaruh Kearifan Lokal, Locus of Control dan Motivasi Terhadap Perilaku Berwawasan Lingkungan Petani Dalam Mengelola Lahan Pertanian di Kabupaten Sopeng. Jurnal Manusia dan Lingkungan.Volume 18, No. 1 . 2011. Pusat Studi Lingkungan Hidup UGM. www.portalgaruda.org : diakses tanggal 2 Mei 2014.

Nasir, Muhammad. 1998. Metode Penelitian. Ghalia Indonesia. Jakarta.

Rahmat, Dedi. 2008. Partisipasi dan Motivasi Peternak dalam Perbaikan Mutu Genetik Domba. Jurnal Ilmu Ternak. Volume 8, No. 1, 2008. Universitas Padjajaran Bandung. www.portalgaruda.org : diakses tangal 5 Mei 2014. 